\title{
Financial and Analytical Tools for Sustainable Business Development in Mining Region
}

\author{
Olga Seklecova ${ }^{1}$, Oxana Komarcheva ${ }^{1}$, and Olga Karpova ${ }^{1, *}$ \\ ${ }^{1}$ Kemerovo state university, 650056, Kemerovo, Stroiteley avenue, 47, Russian Federation
}

\begin{abstract}
The stability of economic entities is the ground for sustainable development of the region. It is customary to group indicators of sustainable development of economic entities in economic, social and environmental terms. The analysis of the economic activity of a typical business unit in an extractive region was carried out based on financial and public non-financial data using the methodology of financial analysis. The authors identified the main development trends and risks of the economic entity.
\end{abstract}

\section{Introduction}

Today, the need to consider indicators of sustainable development in the framework of financial analysis is clearly visible. Assessment of different aspects of the economic entity sustainability implies taking into account the requirements of various stakeholders. The factors of sustainable development of a business entity affect the entire value chain. At the same time, at the enterprise level, sustainability implies the function of maximizing profits within the constraints associated with limited resources, as well as with the influence of social and environmental factors. When investing in business, an economic entity uses human, social, natural and other types of capital.

\section{Materials and Methods}

In the context of the economic crisis, economic entities operating in mining regions require special attention. Since the sectoral structure of the latter is inevitably under pressure from the extractive industries, and characterized by the underdevelopment of the processing sector [1]. The slowdown in economic growth, leading to a decrease in demand for raw materials, increases the negative impact on processing enterprises in the regions. Adapting to such economic conditions, enterprises are forced to cut costs (as a rule, primarily for social and environmental programs), revise strategies, and restructure their businesses. At the same time, sustainable enterprises inevitably have to be innovative, using green technologies, developing human resources. This implies increased attention to change management, focus on long-term development of human capital, integration of sustainable development mechanisms into the management system of an economic entity. The methodological basis for the inclusion of sustainable development aspects in the management mechanism of

* Corresponding author: oskarp@yandex.ru 
economic entities can be the analysis of the financial and economic efficiency of the entity $[2]$.

The integration of sustainable development mechanisms into the activities of business entities is a basic factor in the development and growth of the competitiveness of Russian industrial enterprises and a prerequisite for the active modernization of key industries.

The essence of the concept of sustainable development of economic entities in a generalized form is to ensure stable economic growth while meeting the requirements of social responsibility, starting from the micro-level (economic entity) and ending with the macro-level (region, state and the world community as a whole). Despite the fact that at present this concept can be applied to individual organizations (economic entities), most of the research in the field of sustainable development - both practical and theoretical - is related mainly to the study of macro-systems (individual countries, regions, etc.) [3]. Not enough attention is paid to the sustainable development of economic entities (micro-level), while in modern conditions, by maintaining the sustainability of economic entities, stability at the macro-level (at the level of the region, state and world) can be ensured [4-7].

The concept of sustainable development of an economic entity must be considered in a balanced relationship of its constituent components: social, environmental and economic sustainability. For successful activity, an economic entity needs a three-pronged approach to the sustainable development that is, ensuring a balance of the three designated aspects.

The sustainability of the economic entity development is determined by production, technological, organizational and managerial and human capital, rationality of price, marketing, innovation and investment policies that ensure its financial stability. Thus, economic sustainability consists of financial, marketing, production, technological and organizational sustainability.

\section{Results and discussion}

JSC "Osinnikovsky repair and mechanical plant" (JSC "ORMP") is one of the few industrial enterprises in Osinniki city, which is one of the centers of coal mining in Kuzbass and is included in the list of mono-industry towns. The main activity of the enterprise is the production of building metal structures, products and their parts intended for the coal industry enterprises. A comprehensive assessment of the sustainable development of an economic entity is carried out by stages in three main areas: economic, social, and environmental activity.

The methodological research tools include an analysis of the absolute and relative values of indicators. Analysis of the economic aspects of sustainable development methodically corresponds to a comprehensive analysis of economic activity and financial condition with an emphasis on specific indicators of sustainable development. The source of information for external users will be accounting (financial) statements and other public information. [8-11] At the preparatory stage of the study, it is necessary to familiarize with the financial and nonfinancial statements of the subject, to check the statements for the completeness and consistency of the data provided, in order to make a decision about the possibility and feasibility of further analysis. Further, an economic reading and a detailed analysis of the economic sustainability of an entity are carried out. Evaluation of the effectiveness of activities involves building of an indicators system that determine the effectiveness in achieving business goals. It is generally recognized that the main goal of an economic entity in market conditions is to make a profit from its activities, which allows increasing the value of the company and ensure the growth of the welfare of owners and employees.

The main source of profit is operating activities that combine production and commercial components. [5] 
Table 1. Financial results of JSC “ORMP”, thousand rubles.

\begin{tabular}{|c|c|c|c|c|c|c|c|c|c|}
\hline \multirow{2}{*}{ Indicator } & \multicolumn{4}{|c|}{ Absolute values } & \multicolumn{3}{c|}{$\begin{array}{c}\text { Growth rate compared to } \\
\text { the previous year, \% }\end{array}$} \\
\cline { 2 - 11 } & 2016 & 2017 & 2018 & 2019 & 2020 & 2017 & 2018 & 2019 & 2020 \\
\hline $\begin{array}{c}\text { Revenues } \\
\text { from sales }\end{array}$ & 549658 & 733004 & 881649 & 1072252 & 895753 & 133 & 120 & 122 & 84 \\
\hline $\begin{array}{c}\text { Operating } \\
\text { profit }\end{array}$ & 12674 & 37568 & 56072 & 63513 & 38540 & 296 & 149 & 113 & 61 \\
\hline $\begin{array}{c}\text { Earnings } \\
\text { before } \\
\text { interest }\end{array}$ & 16534 & 42228 & 61730 & 68610 & 45113 & 255 & 146 & 111 & 66 \\
\hline \begin{tabular}{c} 
Net profit \\
\hline
\end{tabular} & -72 & 26092 & 48542 & 49299 & 29338 & - & 186 & 102 & 60 \\
\hline
\end{tabular}

The data in Table 1 indicate an increase in the volume of products sold over the past five years by $63 \%$. Despite the reduction in 2020 , due to the spring lockdown, the company was able to provide a level of revenue higher than the value of 2018 , for the same period there are no facts of termination of any activities by the company. However, today it is impossible to fully assess the degree of destructiveness as the consequences of the COVID-19 pandemic and the impact on the financial condition and results of the enterprise in future reporting periods.

The negative value of the net profit indicator in 2016 is associated with the consequences of the financial crisis that began in the second half of 2014 and continued in 2016, which had a significant impact on the coal industry in general and JSC "ORMP" in particular. The company's dependence on the state of affairs in ferrous metallurgy is a serious risk for JSC "ORMP". A significant decrease in prices for metal and metal products resulted in a decrease in market prices for the products supplied by the Company. The Company is highly dependent on prices for basic (metal), auxiliary materials, etc. Therefore, their growth had a negative impact on the financial performance of the Company. Net profit in 2016 has a negative value; this is due to the excess of the amount of income tax over the amount of profit before tax. At the same time, the largest value in the amount of the current tax is made up of permanent tax liabilities (assets), which have doubled compared to 2015.

From 2017 to 2019, there was a tendency for profit growth at the enterprise. However, the crisis events of 2020 led to an outstripping decrease in revenue compared to cost of sales and other expenses, which led to a faster rate of decline in profits. However, the net profit in 2020 was $12.4 \%$ higher than in 2018.

Table 2. Absolute indicators of financial stability of JSC “ORMP”, thousand roubles.

\begin{tabular}{|c|c|c|c|c|c|}
\hline \multirow{2}{*}{ Indicator } & \multicolumn{5}{|c|}{ Year } \\
\cline { 2 - 6 } & 2016 & 2017 & 2018 & 2019 & 2020 \\
\hline Own funds & 127034 & 153124 & 201666 & 250965 & 280303 \\
\hline Fixed assets and investments & 34587 & 38056 & 29092 & 34595 & 37949 \\
\hline Own working capital & 92447 & 115068 & 172574 & 216370 & 242354 \\
\hline
\end{tabular}




\begin{tabular}{|c|c|c|c|c|c|}
\hline Long-term loans and borrowings & 2023 & 2297 & 1994 & 2262 & 2087 \\
\hline Own and long-term borrowed funds & 94470 & 117365 & 174568 & 218632 & 244441 \\
\hline Short-term loans and borrowings & - & - & - & - & - \\
\hline The main sources of stocks and costs & 94470 & 117365 & 174568 & 218632 & 244441 \\
\hline Inventories and costs & 43144 & 51485 & 60011 & 99414 & 62590 \\
\hline $\begin{array}{c}\text { Surplus or shortage of own working } \\
\text { capital }\end{array}$ & 49303 & 63583 & 112563 & 116956 & 179764 \\
\hline $\begin{array}{c}\text { Surplus or shortage of own and long-term } \\
\text { borrowed funds }\end{array}$ & 51326 & 65880 & 114557 & 116218 & 181851 \\
\hline $\begin{array}{c}\text { Surplus or shortage of the main sources of } \\
\text { formation of stocks and costs }\end{array}$ & 51326 & 65880 & 114557 & 116218 & 181851 \\
\hline Financial strength type & $1,1,1$ & $1,1,1$ & $1,1,1$ & $1,1,1$ & $1,1,1$ \\
\hline
\end{tabular}

Absolute indicators characterize financial stability from the standpoint of sources of the company's current assets in terms of stocks and costs. The data in Table 2 indicate the absolute type of financial stability of JSC "ORMP", in which the enterprise fully covers the reserves and costs with its own sources. The lack of short-term loans, on the one hand, may adversely affect profitability, but in the current economic crisis, it is one of the potential opportunities for improving the financial condition, if necessary. At the same time, all three indicators of coverage of stocks by own circulating assets for the analyzed period improved their values, so own circulating assets (own circulating capital) increased in 2.6 times.

To assess the financial state in addition to absolute values, coefficients that compare various indicators are used.

Table 3. Ratio analysis of the financial state of JSC "ORMP" .

\begin{tabular}{|c|c|c|c|c|c|c|}
\hline \multirow{2}{*}{ Indicator } & \multicolumn{5}{|c|}{ Year } & $\begin{array}{c}\text { Growth } \\
\text { rate, \% }\end{array}$ \\
\cline { 2 - 7 } & 2016 & 2017 & 2018 & 2019 & 2020 & $\begin{array}{c}2020 / \\
2016\end{array}$ \\
\hline Autonomy ratio & 0.19 & 0.21 & 0.22 & 0.40 & 0.49 & 258 \\
\hline Equity to debt capital ratio & 0.23 & 0.26 & 0.28 & 0.67 & 0.96 & 417 \\
\hline $\begin{array}{c}\text { Maneuverability coefficient } \\
\text { Coefficient of provision with own } \\
\text { circulating assets }\end{array}$ & 0.73 & 0.75 & 0.86 & 0.86 & 0.86 & 118 \\
\hline Absolute liquidity ratio & 0.0011 & 0.009 & 0.001 & 0.001 & 0.013 & 1182 \\
\hline Quick (intermediate) liquidity ratio & 1.1 & 1.1 & 1.2 & 1.3 & 1.6 & 145 \\
\hline Current (total) liquidity ratio & 1.2 & 1.2 & 1.25 & 1.6 & 1.8 & 150 \\
\hline Return on sales & 2.3 & 5.1 & 6.4 & 5.9 & 4.3 & 187 \\
\hline Product profitability & 2.4 & 5.5 & 6.9 & 6.4 & 4.6 & 192 \\
\hline
\end{tabular}




\begin{tabular}{|c|c|c|c|c|c|c|}
\hline Return on equity & 0.06 & 17.0 & 24.1 & 19.6 & 10.5 & 175 \\
\hline Return on assets (property) & - & 3.5 & 5.2 & 7.9 & 5.1 & - \\
\hline Asset turnover ratio & 0.6 & 1.0 & 1.0 & 1.8 & 1.7 & 283 \\
\hline Inventory turnover ratio & 12.7 & 14.2 & 14.7 & 10.8 & 14.3 & 113 \\
\hline Accounts receivable turnover ratio & 0.9 & 1.1 & 1.1 & 2.2 & 1.9 & 211 \\
\hline
\end{tabular}

From the data in Table 3, it follows that JSC "ORMP" in the period under review demonstrates a growth trend in financial stability. Equity capital increased every year, over five years the share of equity capital in the balance sheet total increased in 2.579 times, the share of equity capital accounted for almost half of the sources of property. If in 2016 the ruble of borrowed funds accounted for 23 kopecks of own, then in 2020 for each ruble of borrowed capital, the enterprise provided 96 kopecks of equity capital. The maneuverability coefficient indicates that a high share of equity capital is in mobile form. By the end of the analyzed period, equity capital covers almost half of the current assets. Thus, JSC "ORMP" demonstrates a tendency to strengthen financial stability with high capital mobility.

Liquidity ratios indicate problems with ensuring solvency in the short term. With a standard value of at least 0.2 , the absolute solvency ratio has a maximum value of 0.013 , that is, the company is able to repay immediately only about $1 \%$ of its short-term liabilities. The quick (intermediate) liquidity ratio characterizes the payment capabilities of the enterprise, subject to the demand of receivables. This ratio indicates the ability of the enterprise to repay fully its short-term obligations at the expense of accounts receivable. The most generalizing is the current liquidity ratio, which in the period under review has an upward trend and by 2020 is at the recommended level. The ratio of the indicators of the most liquid assets and the most urgent liabilities does not meet the standards, JSC "ORMP" does not have enough cash and short-term financial investments to repay the most urgent ones, but otherwise the ratio of all indicators meets the liquidity requirements.

Profitability indicators in the period under review demonstrate uneven dynamics, growth is observed until 2018 and a decrease in 2019-2020 in relation to the previous period. However, all indicators of profitability in 2020 significantly exceed the corresponding levels in 2016, that is, in five years there was an increase in profitability indicators.

The growth in profitability was accompanied by the intensification of the use of assets, the asset turnover increased in 2.83 times, the period of asset turnover decreased to 217 days. However, despite the twofold acceleration of the turnover of accounts receivable, the period of its return remains quite long. This situation is a source of risk to financial stability and requires special attention.

Thus, the analysis of the financial and economic efficiency of JSC "ORMP" made it possible to establish positive trends in the growth of profits and profitability, the growth of equity capital and overcoming dependence on borrowed capital, an increase in its own working capital, and a sufficiently secured solvency of the enterprise. However, we should pay attention to the problems with a long period of return of receivables, the situation with short-term solvency and a turning point in the change of profitability indicators.

Assessment of the social efficiency of activities includes the following components: the stability of the staff; the level of education (development) of personnel; sustainability of material support for employees: the level of labor protection; social programs.

For the analyzed five years, the number of personnel of "ORMP" JSC increased from 77 to 89 people. At the same time, there is an increase in the number of people in the main activity personnel per one employee in the non-main activity. On the positive side, there is 
an increase in production personnel per administrative employee. This is confirmed by a decrease in the share of administrative employees in the total headcount, which decreased by $3.1 \%$. In general, from the point of view of labor force provision, the enterprise is in a favorable situation for increasing production output. The main share of the plant's employees is between 20 and 50 years old, which speaks of a mature but rather young team. Most organizations that produce similar products usually employ men. Moreover, the management mostly consists of men. The analyzed organization is no exception. The majority of the company's employees are men, and their share increased from $87 \%$ in 2016 to $90 \%$ in 2020 . Among managers, there is an unequal ratio of men and women, more than $80 \%$ are men. Note that among specialists, the ratio of men and women is approximately equal.

In the analyzed period, the efficiency of labor resource at the enterprise has increased. This is evidenced by the increase in all indicators of production. So, in the reporting year, the output of industrial and production personnel increased by $29 \%$, the output of a worker by $27 \%$.

The indicators of labor resources and labor productivity are considered in relation to the wages of workers, optimally when the growth rate of wages is slightly lower than the growth rates of labor productivity. According to these indicators, the enterprise observes the principle of rational organization of labor, so the rate of growth of the wage fund of industrial and production personnel for five years amounted to $37 \%$, and the wage fund increased by $41 \%$.

The analysis of labor protection level in the organization revealed that the number of workers who were diagnosed with occupational diseases was less than one percent, at the same time there is a decrease in the frequency of registered occupational diseases.

Thus, a comprehensive assessment of the social efficiency of JSC "ORMP" showed that during the analyzed period there was an increase in the share of personnel under the age of fifty, which is a positive trend. As this particular category of employees is the human potential for an economic entity, there is a constant modernization in the field production, labor protection, industrial safety.

JSC "ORMP" tries to create a production that would simultaneously serve two key goals of sustainable development - to provide consumers with the necessary products and to preserve the natural environment. Preservation of the environment is a strategic priority of the enterprise when making managerial and production decisions. The enterprise regularly monitors the quality of discharges of pollutants into a natural water body, the quality of emissions into the atmospheric air and the quality of atmospheric air at the boundaries of sanitary protection zones. These types of work are carried out in accordance with the measurement program and eco-analytical control schedules agreed with the regulatory authorities, by the accredited sanitary and environmental laboratories in the cities of Osinniki and Kaltan. The environmental monitoring program has been fully completed for the analyzed period.

\section{Conclusion}

Thus, the assessment of JSC "ORMP" activities in the field of sustainable development, carried out using financial and analytical tools, showed that a positive trend of strengthening financial independence was formed in the company during the study period, an increasing share of the company's assets is provided by its own sources of financing. Financial sustainability is ensured by the organization's ability to meet timely the current and long-term financial requirements of stakeholders as a result of effective management of available and attracted resources.

A comprehensive assessment of the social efficiency of JSC "ORMP" revealed that modernization is constantly taking place in the field of production, labor protection, and industrial safety. The environmental efficiency assessment of JSC "ORMP” testified that for 
the analyzed period environmental protection activities were carried out in accordance with the legislation of the Russian Federation on environmental protection. The environmental aspect plays an important role in the development of the company. JSC "ORMP” works to reduce the negative impact on the environment through the introduction of new technologies in production processes, and pays great attention to monitoring and measures to preserve biodiversity in the region. The main indicators requiring the attention of economic actors, especially in mining regions are protection and restoration of the environment, rational consumption of energy water and other resources, estimation of irreplaceable resource volume. To continue the list there are also comprehensive measures to reduce energy consumption, control over the quality of the atmosphere in the region by leveling negative consequences, minimization of emissions into the atmosphere of various categories of pollutants, recycling and reuse of materials and resources.

The strategic priorities for the sustainable development of the organization are enshrined in corporate documents that determine the general principles of work and the procedure for implementing the strategy in key areas. In accordance with the best international practices, JSC “ORMP" integrates the principles of social responsibility into decision-making processes and operational activities. The system of key performance indicators adopted in the organization is aimed at effective solution of both direct production tasks and tasks in the field of sustainable development. Annual goals include indicators of industrial safety, development of social and charitable activities, and cooperation with stakeholders.

\section{References}

1. K. Schwab, La cuarta revolución industrial (Peguin Random House Grupo editorial, Barcelona, 2016)

2. P.V. Jenster, D. Hussey, Company Analysis: Determining Strategic Capability (Wiley, London, 2002)

3. Global Risk Report (World Economic Forum, Geneva, 2019)

4. C. Braymen, Y.-M. Chang, Z. Luo, Pacific Economic Review, 2, 76 (2016)

5. A. Anisimov, D. Motorin, International Journal of Interdisciplinary Environmental Research, 3-4, 21 (2019)

6. Saleh Al-Muzaini, Arab Journal of Science and Technology, 2:28, 161 (2003)

7. Yu. V. Shumilov, M. Yu. Shumilova, Eurasian Scientific Association, 2:2(24), 159-162 (2017)

8. W. T. Harrison, C. T. Horngren, Financial accounting (Pearson Education, London 2008)

9. G.A. Porter, C.L. Norton, Using Financial Accounting Information: The Alternative to Debits and Credits (South-Western College Pub, Nashville, 2010)

10. D.P. Baron Business and Its Environment (Prentice Hall, New Jersey, 2003)

11. T.H. Davenport, M. Leibold, S.C. Voelpel, Strategic Management in the Innovation Economy: Strategic Approaches and Tools for Dynamic Innovation Capabilities (Wiley, London, 2006) 